\title{
Developing Educational Media of Health Protocol utilizing Live Coloring using Augmented Reality Technology
}

\author{
Akbar Permana Putra ${ }^{1}$, Priyanto ${ }^{2}$ \\ 1,2 Electronics Technology and Informatics Education, Yogyakarta State University \\ E-mail: akbarpermana.2019@student.uny.ac.id
}

\begin{abstract}
The high rate of spread of the coronavirus is increasing, currently (August 7, 2021) in Indonesia the number of deaths from the coronavirus has reached 105,598 people and continues to increase every day. The spread of the coronavirus can be prevented by implementing health protocols that must be applied by everyone, including children. In educating children, interesting media is needed by utilizing technological developments. This study aims to produce a learning media product applying health protocols to children with the title "Beware of the coronavirus". This media was developed using the Research \& Development method through several stages, namely research and initial data collection, research planning, product development, expert validation, product revision, and final product. The feasibility test is carried out by media experts by testing the domain of multimedia construction with 3 aspects, namely guidance and information, program performance, and systematic, aesthetic, and design aspects. Data was collected using a questionnaire filled out by media experts. This study uses descriptive statistical data analysis techniques. The result of the product is an educational media in implementing the $3 \mathrm{M}$ health protocol, namely wearing masks, washing hands, and maintaining a safe distance. Augmented reality technology with live coloring features is added so that children can color marker objects and appear in 3D to increase children's attractiveness. The results of validation to experts showed that children's education media in implementing the $3 \mathrm{M}$ health protocol was in the very feasible category with an assessment result of 4.81 so that learning media could be used and applied to children with parental assistance.
\end{abstract}

Keywords: educational media, health protocol, augmented reality

\section{INTRODUCTION}

Education on health protocols such as washing hands, maintaining distance, and using masks is the government's focus in preventing and controlling the spread of Covid-19[1]. Currently, health protocols must be applied by everyone, including children, adolescents, adults, and the elderly [2]. people who are less active and negligent in implementing health protocols and the lack of educational media have an impact on the increase in cases of the coronavirus, so it is necessary to increase knowledge in implementing health protocols through media that are familiar to the public such as educational videos that can be uploaded on social media such as Facebook, Instagram and WhatsApp [3]. This is supported by research results which state that in addition to print media, social media is the most widely used online media in delivering information related to the implementation of health protocols to avoid the spread of the coronavirus [4].

Severe Acute Respiratory Syndrome Coronavirus 2 (SARS-CoV-2) or is known as Corona Virus (Covid-19) is a virus that attacks the respiratory system. The Coronavirus can cause disturbances in a person's respiratory system, lung infections, and death cause[5]. The Coronavirus is a new type of disease and needs to watch out for the cause of its spread so fast [6]. WHO (World Health Organization) officially announced that the Coronavirus outbreak was a pandemic on 12 March 2020 [7].

In Indonesia, the first case of Covid-19 Has reported on March 2, 2020 [8], Nowadays, the Covid-19 case has spread in 34 provinces which consist of 3,639,616 cases with 105,598 deaths as of August 7, 2021 [9]. This number continues to increase with the high level of the 
spread of covid-19. The Covid-19 virus can be transmitted directly from person to person, so its spread is very aggressive. Spread through respiratory droplets that come out when sneezing or coughing[10]. The spread of the Covid-19 can be prevented by using personal protective equipment (PPE) such as masks and protective glasses (face shield)[11].

Various media such as printed leaflets, posters, books to e-books are published as a medium for delivering information related to the implementation of health protocols [12]. Several e-book media related to the coronavirus have also been published by the Ministry of Women's Empowerment and Child Protection of the Republic of Indonesia as a medium for educating children at home such as the ebook entitled Getting to Know COVID-19, Happy to Study at Home, Let's Be a Pioneer and Reporter (2P) to Prevent the Spread of COVID-19[13].

Wardhani et al. [14], who developed an audio-visual learning media as a medium to educate children in implementing health protocols, said that the media was expected to provide knowledge and increase children's sensitivity in maintaining personal hygiene and being aware of the dangers of coronavirus transmission. Solichah and Fadhilah [15] socialized health protocols using coloring activities in early childhood using the media "Damar Kurung". Damar Kurung is a product of Gresik East Java local culture in the form of cube lanterns, the sides of the lanterns are made of paper that can be decorated and colored, children are asked to draw and color the side of the resin brackets with health protocol content. Prasetiyo and Sutama [16] use the internet as a means of introducing COVID-19 to early childhood, using internet-based platforms such as YouTube and websites is considered more interactive and less boring than reading books or other media. While Hanafi et.al [17] developed an augmented reality-based mobile application as an educational medium on how to wash hands properly to avoid the spread of the coronavirus.

However, it is not easy to educate children regarding Covid-19 virus prevention, some problems often occur when educating children. for example, they can't follow instructions or don't focus [18]. This phenomenon encourages researchers to find solutions in educating the application of health protocols to children using familiar media.

The use of mobile-based educational media is considered can attract attention in the learning process [19]. Recent advances in technology are being implemented effectively in the educational context. One of them is using Augmented Reality technology. Augmented reality (AR) is a technology that takes advantage of the existing environment and superimposes new information (virtual world) on it using 2D and 3D animation visualization features[20]. Augmented reality can be used as an effective educational medium in improving children's cognition [21]. Students can interact with the real world and the virtual world directly (real-time) [22]. This interaction can be an intermediary for children in learning something by providing an interesting learning experience [23].

Augmented Reality (AR) can create magical feelings for children and provide an interesting learning experience [21]. Clark and Dunser[24] present a new kind of augmented reality in coloring media, this work allows users to color books, and the system automatically maps colors and displays them in 3D. It is a pioneer for other commercial products such as Crayola Color Alive and Disneys Color and Play [25].

Although there are many methods used in educating children in implementing health protocols, ranging from advice through television media, internet media, and others, it takes a unique medium through new learning methods [26]. The use of learning media can certainly overcome all forms of limitations in the learning process so that it can make it easier for students to understand the material [27]. According to Utami [28], the best learning technology is by learning needs based on the characteristics of students. Augmented Reality can be a solution in creating an interesting learning process and improving student skills 
[29]. However, no references have been found regarding the use of AR technology using the live coloring feature to support the health protocol process in children. This is supported by Bacca et al [30] who found that the use of AR is mostly carried out at the secondary and tertiary levels, while research studies on preschool education are very limited. In addition, Khalid [31] stated that most of the 3D live coloring products are only used as games and media for fun.

Based on the existing background, it is necessary to develop an AR-based learning media "Awas Ada Virus Corona" which can be used to educate health protocols for children. Augmented Reality technology can create a magical experience for children [22]. The product was developed by adding a "live coloring" feature to markers to increase children's attractiveness using familiar media. Augmented Reality technology is applied so that children don't only focus on gadgets but also carry out activities and interactions with the environment [32].

\section{METHOD}

This study utilized research and development methods using the Borg \& Gall model [33]. Research and development is research that is used to produce a product and test it [34]. In this study, researchers used level 3 (scale 4), namely researching to develop existing products. The result of this study is an Augmented Reality-based learning media with a "live coloring" feature that is used to educate children in implementing health protocols in preventing the spread of the coronavirus. The stages of research and development proposed by Borg \& Gall consist of 10 (ten) steps. While developing this learning media uses six stages only. The use of these six stages is applied to facilitate the research process without reducing the actual meaning and function of each step. The learning media development procedure used is preliminary research and data collection, research planning, product development, expert validation, product revision, and final product. The development stage is illustrated in Fig.1.

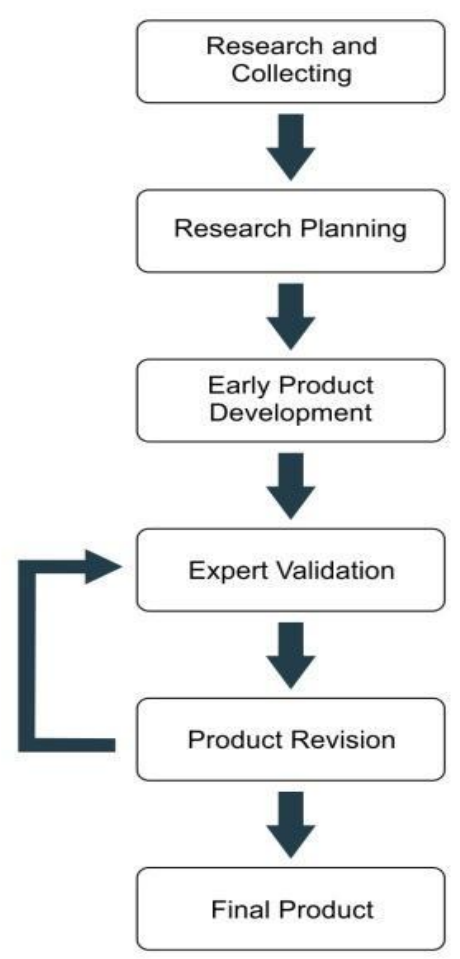

Figure 1. Development procedure

At the development stage, the resulting learning media is an android-based application that is used to scan markers in the form of coloring paper/media. Several features developed, are an information menu, a user guide menu, materials related to health protocols, a video menu, and an "augmented reality live coloring" menu that raises a 3D object according to the color printed on the marker. The media was developed using the supporting software presented in table 1 .

Table 1. The software used in developing applications

\begin{tabular}{|c|c|c|}
\hline No & Software & Function \\
\hline 1 & Blender & Create 3D object \\
\hline 2 & Corel Draw & Create a user interface (UI) \\
\hline 3 & Unity & $\begin{array}{c}\text { Producing smartphone-based } \\
\text { application media }\end{array}$ \\
\hline 4 & $\begin{array}{c}\text { Adobe } \\
\text { Photoshop }\end{array}$ & $\begin{array}{c}\text { Producing content on the } \\
\text { application }\end{array}$ \\
\hline $\mathbf{5}$ & Vuforia & $\begin{array}{c}\text { Augmented Reality Software } \\
\text { Development Kit (SDK) for }\end{array}$ \\
\hline
\end{tabular}




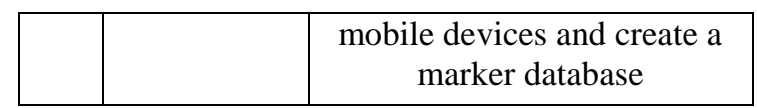

The data analysis used in this research process used quantitative descriptive analysis. The data obtained were analyzed using descriptive statistics. The data on the questionnaire used in the validation of media experts used quantitative data on a Likert scale. The data obtained were then converted on a scale of 4 then interpreted descriptively.

Table 2. Questionnaire Scale

\begin{tabular}{|c|c|}
\hline Score & Interpretation \\
\hline 1 & Not feasible \\
\hline 2 & Less feasible \\
\hline 3 & Feasible \\
\hline 4 & Very feasible \\
\hline
\end{tabular}

\section{RESULT AND DISCUSSION}

The product developed in this study is a learning media "Awas Ada Virus Corona" with an augmented reality feature which is using "live coloring" technology. The stages of developing this learning media include:

\section{A. Preliminary research and data collection}

The stages of preliminary research and data collection that have been conducted in this study include literature review, problem identification, and observation related to making learning media applying familiar and interesting health protocols for children. Besides that, the analysis of system requirements in making applications is also conducted, both in terms of software and hardware.

Data collection was carried out using a literature review which showed the results that health protocol education media was still limited with print media and social media (Facebook, WhatsApp, and Instagram) which were less familiar with children, this was supported by the interview method that had been conducted with parents who have children. aged 3-6 years, the interview results show that a new media that attracts attention is needed in educating children about the application of health protocols using familiar media.
The development of health protocol education media requires some software in the creation of display content and data storage (databases) that are used to store marker objects as markers during the augmentation process. In addition, in the manufacture of threedimensional objects, hardware that has qualified specifications is needed, such as RAM (random access memory) with a minimum capacity of 2 gigabytes, a minimum hard disk free space capacity of 20 gigabytes, and a graphics card above 2004.

\section{B. Research Planing}

Research planning is conducted by compiling a storyboard. The storyboard is a design sketch of the application to be developed. Making storyboards is done to make it easier for developers to prepare materials and content that is tailored to the needs of the process of developing health protocol education media. Storyboards are made sequentially and form a storyline based on the product [35]. The learning media storyboard of "Awas Ada Virus Corona" is shown in the descriptions of the following pictures.

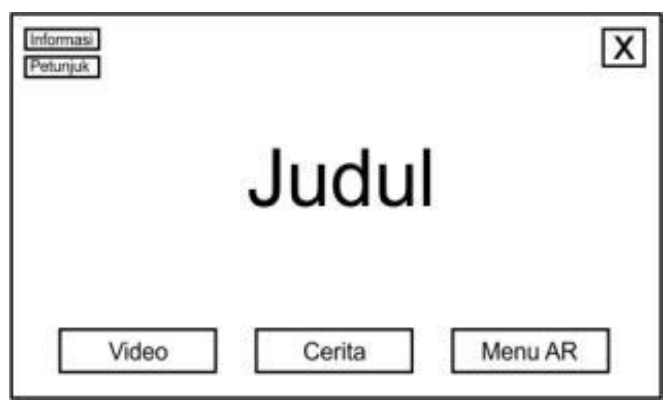

Figure 2. Main Page

Fig,2 shows the title from the health protocol media, namely "Beware of the coronavirus" which is designed using animated images, on this page, there are also 3 menus on the main page, namely the video menu, the story menu, and the AR menu. At the top right, there is an application exit button. On the top left, there is an information menu that leads to the information page of the application, and there is a hint button that leads to the manual user page, and the function of the buttons. 


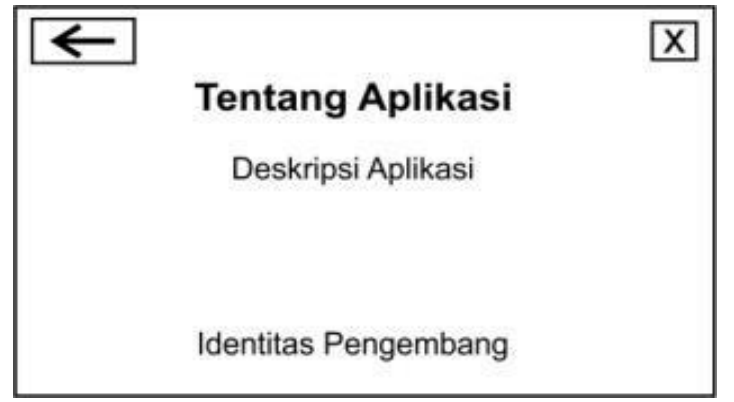

Figure 3. Application Info Page

Fig. 3 shows the application info display. This menu contains the title "Tentang Aplikasi" (about application) and a description of the application and developer information. There is a back button in the left corner of the main page. Whereas the exit button on the upper right corner there is an.

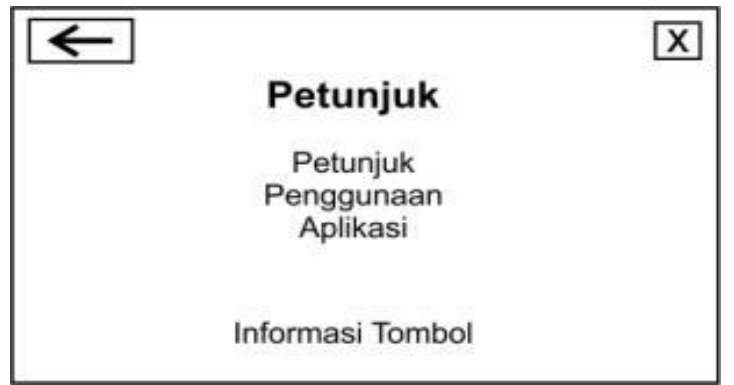

Figure 4. Instruction Page

Fig.4 shows the instruction page display. The direction page contains the title "Petunjuk penggunaan aplikasi" (application usage guide) accompanied by an explanation about the functions of the buttons on the application such as the button to the material page, the button to the video page, and the button to the live coloring page. There is a back button in the upper left corner leading to the main page and the exit button in the upper right corner.

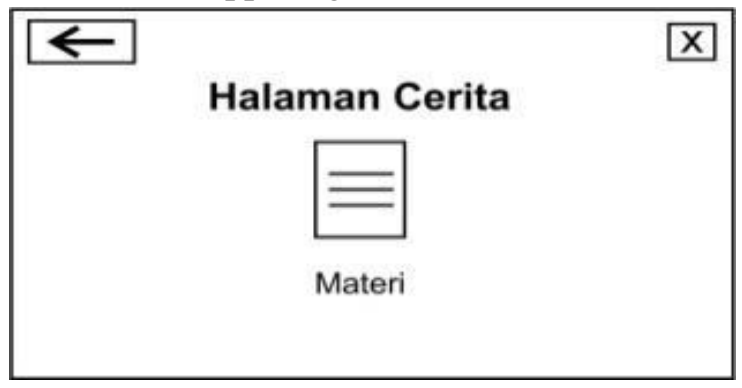

Figure 5. Material Page

Fig.5 shows the material page display. The material page contains the coronavirus story in an illustration form that can be read by parents related to the dangers of coronavirus education and how to prevent transmission of the coronavirus. This material page is designed using cartoons and full-color illustrations to make it interesting for children to see and learn.

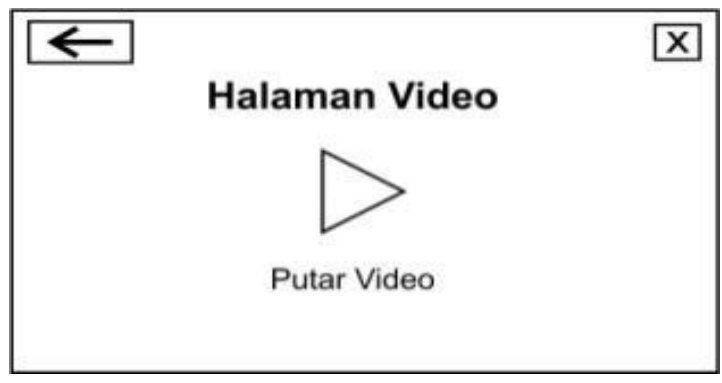

Figure 6. Video Page

Fig.6 shows the video page display. An animated video entitled "Awas ada virus corona" is presented on this page, videos in the form of educational videos related to basic knowledge about the coronavirus, its transmission, and prevention. The video is accompanied by audio to make it more interesting and not boring.

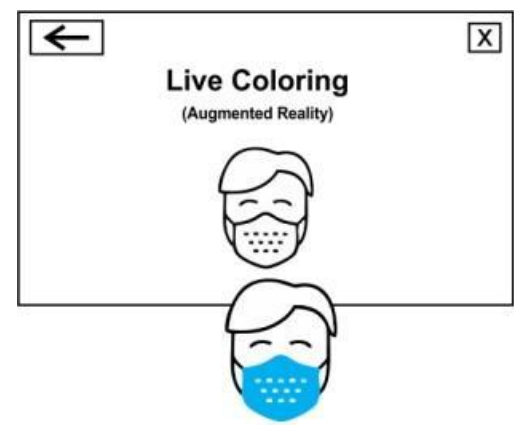

Figure 7. AR Page (Live Coloring)

Fig.7 shows the AR page with a live coloring display. This page will display the camera screen on the phone and can be pointed at the object that has been colored, when the camera detects the marker as an augmentation marker then the scan results will show a 3D object from the colored image by the children

\section{Product Development}

The developed product is a learning media based on augmented reality with a "live coloring" feature for children. This product has several main menus, such as the main page of the 
application, about application page, direction page, material page, video page, and AR page.

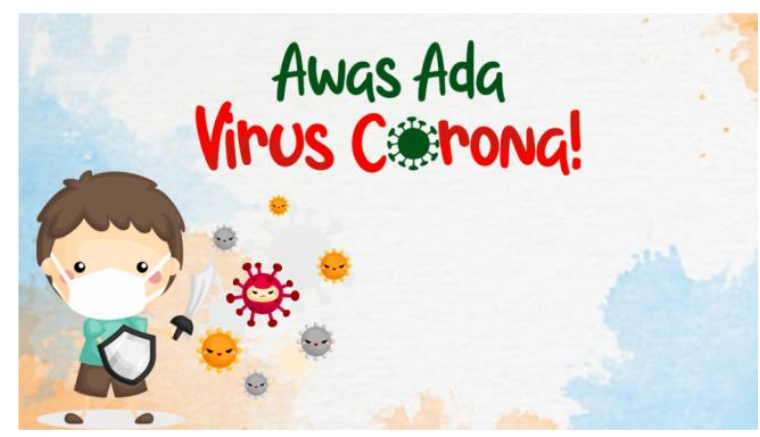

Figure 8. Main Page

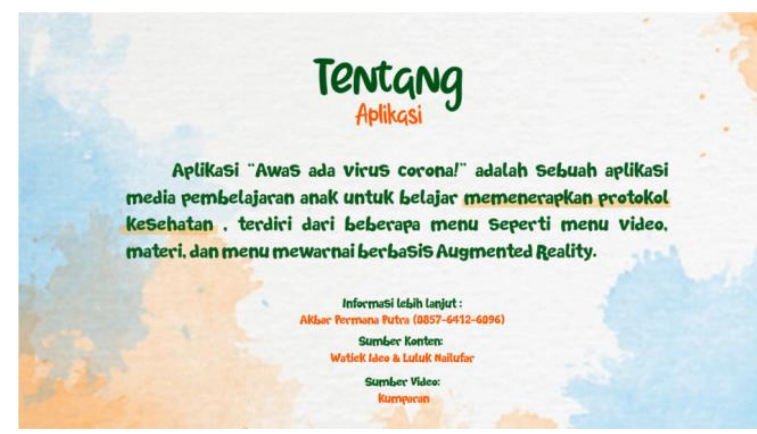

Figure 9. About Application Page

There are several menu buttons on the new main page display, leading to existing sub-pages such as the material menu, videos, and live coloring shown in Fig.8. The page contains application and developer information shown in Fig.9.

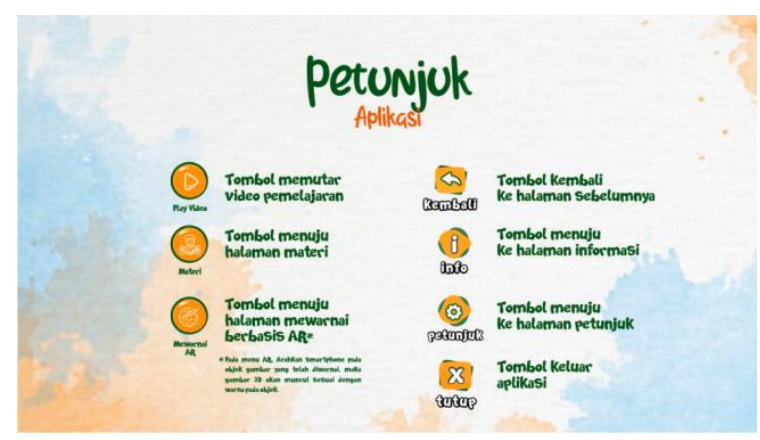

Figure 10. Instruction Page

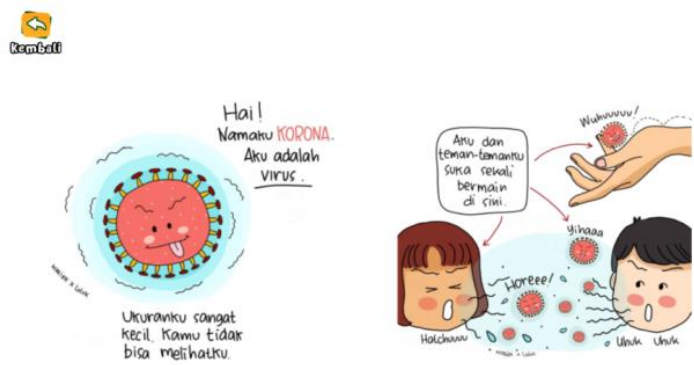

Figure 11. Material Page

Fig.10 shows the development of the instruction page display. This page contains a description or function for each button and how to use them. The material page shows the parents needed role in telling what is the coronavirus and how it spreads. The material is in a storybook form shown in Fig 11.

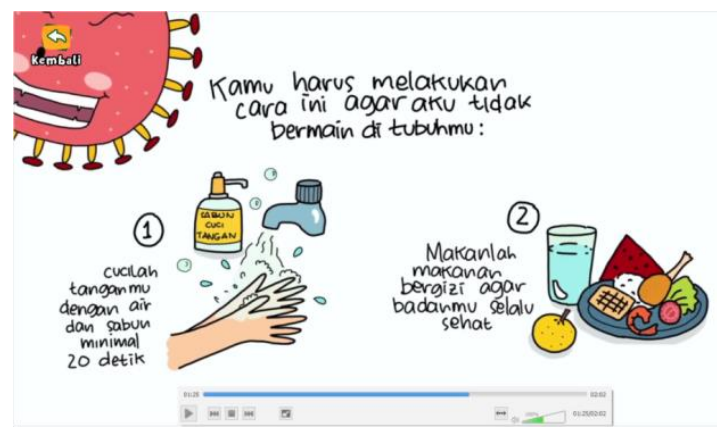

Figure 12. Video Page

Fig. 12 shows the video page display. This page presents an animated video regarding basic knowledge of the coronavirus. Presenting the material in animated video form is expected able to make children will more like the content and be more interested.

The last development page is AR (live coloring). The AR (live coloring) page is an excellent feature of this product. This product expected children will feel more interested in the presented content by utilizing the augmented reality feature. This application is equipped with a coloring book that is used as a scanner marker so that $3 \mathrm{D}$ objects can be seen from the smartphone. After the marker image is scanned, 
a 3D object will appear according to the color of the object colored by the child.

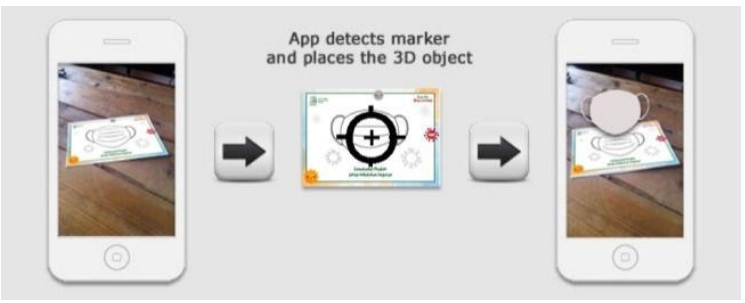

Figure 13. Marker-based applications work

This product is suitable for use for early childhood because the object used as a marker is an image outline that can be colored. When a three-dimensional object appears on the camera, the object can be directed and adjusted as large and small as needed, so that it is as if the child is wearing a mask according to the image he has colored as shown in Fig.14.

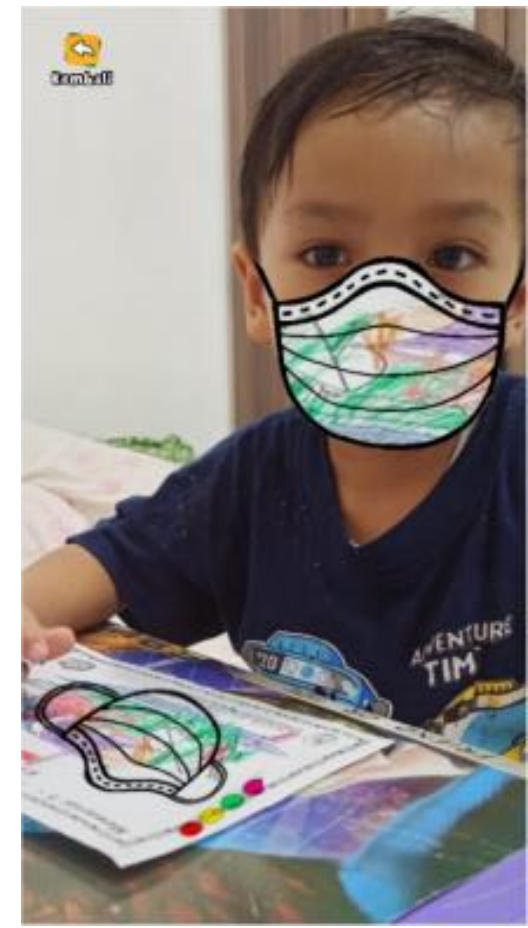

Figure 14. Live Coloring Page

\section{Expert Validation}

The multimedia construction domain testing is conducted by three media experts to validate the Learning media product feasibility. There are 38 statement items from 3 aspects, including 3 statement items from the guidance and information aspects, 10 statements from the program performance aspects, 25 statements from the systematic, aesthetic, and design aspects.

The response of each statement is shown in the numbers 1 to 4 . The results of the scores are tabulated and calculate the average score. The feasibility level is divided into four groups, with an ideal average (2.50) as the eligibility threshold score. The percentage score is calculated by the following formula [36]:

$$
x=\frac{\sum X}{n}
$$

$\mathrm{X}$

$\sum \mathrm{X} \quad$ : The sum of the total values observed

$n \quad$ : Number of statement items

The value obtained is interpreted in the feasibility level as in the following table [36]:

Table 3. Feasibility Interpretation

\begin{tabular}{|c|l|l|}
\hline No & $\begin{array}{c}\text { Mean Interval } \\
\text { Score }\end{array}$ & \multicolumn{1}{|c|}{ Interpretation } \\
\hline 1 & $1,00-2,49$ & Not feasible \\
\hline 2 & $2,50-3,32$ & Less feasible \\
\hline 3 & $3,33-4,16$ & Feasible \\
\hline 4 & $4,17-5.00$ & Very feasible \\
\hline
\end{tabular}

Based on the media expert's assessment, the questionnaire results show a feasibility score of 4,81 which is categorized into the Very feasible category, because the product is easy to use, attractive appearance, and uses attractive features.

\section{E. Product Revision}

The product validation assessment results become a reference at the product revision stage then become the final product, namely the learning media "Awas Ada Virus Corona" using Augmented Reality technology with a live coloring feature. Under the input provided by the validator, changes are made to the type of writing and the color of the button, there is the addition of a zoom feature on objects that appear in three-dimensional form so that users can adjust augmented objects to the real world. 


\section{F. Final Product}

The final product of this learning media is the final product of the revisions that have been made in the previous stage. Revisions that have been made are changes in the type of writing and the color of the buttons, revisions are made so that the writing looks clearer and legible. A three-dimensional object magnification feature has also been added to the final product, the addition of this feature is made to make it easier for users to adjust three-dimensional objects. The three-dimensional object zoom feature can be used by pinching (swiping the thumb and index finger) outwards on the phone screen.

\section{CONCLUSION}

Based on the result of this research, it can be concluded that: (1) this research has resulted in an augmented reality-based learning media product with a "live coloring" feature as a medium for educating children in implementing a health protocol entitled "Awas Ada Virus Corona". This learning media contains educational content and appeals so as not to be infected with the coronavirus, (2) the products developed are determined as a very feasibility category. After being tested by three media experts and passing several revisions, this product can be used and applied to children with parental assistance. (3) the product testing by media experts only on the feasibility of media construction. The researchers hope this product can be tested on the users and the effectiveness test can be conducted in the future.

\section{DAFTAR PUSTAKA}

[1] Inpres Republik Indonesia, Peningkatan disiplin dan penegakan hukum protokol kesehatan dalam pencegahan dan pengendalian corona virus 2019, no. 031242. 2020.

[2] WHO, "Critical preparedness, readiness and response actions for COVID-19," no. June, pp. $1-10,2020$.

[3] A. Rosidah, B. A. Khasanah, and R. Kayis, "Meningkatkan Kesadaran Masyarakat Terhadap Pencegahan Covid-19 Melalui Video Edukasi Penerapan Protokol Kesehatan," Logista J. Ilm. Pengabdi. Kpd. Masy., vol. 4, no.
2, pp. 414-419, 2020.

[4] A. Iskandarsyah, "Information provision about Covid-19, helath behaviors and mental health in Indonesia: Results from survey among 3,686 respondents.," Kementerian Riset dan Teknologi - Badan Riset dan Inovasi Nasional Republik Indonesia, 2020. [Online]. Available: Sinta.ristekbrin.go.id. [Accessed: 12-Jun-2020].

[5] WHO, "Novel coronavirus 2019," 2019. [Online]. Available: https://www.who.int/emergencies/diseases/nov el-coronavirus-2019. [Accessed: 15-Sep-2020].

[6] A. Susilo et al., "Coronavirus Disease 2019: Review of Current Literatures," vol. 7, no. 1, pp. 45-67, 2020.

[7] WHO, "WHO Director-General's opening remarks at the media briefing on COVID-19," 2020.

[8] WHO, "Coronavirus disease 2019 (COVID19)Situation Report -42," 2020. [Online]. Available: https://www.who.int/docs/defaultsource/coronaviruse/situationreports/20200302-sitrep-42-covid19.pdf?sfvrsn=224c1add_2.10. [Accessed: 15Sep-2020].

[9] Satuan Tugas Penanganan Covid-19, "Peta sebaran covid-19 di Indonesia," 2020. [Online]. Available: https://covid19.go.id/peta-sebaran. [Accessed: 16-Sep-2020].

[10] Y. Han and H. Yang, "The transmission and diagnosis of 2019 novel coronavirus infection disease (COVID-19): A Chinese perspective," Journal of Medical Virology, vol. 92, no. 6. pp. 639-644, 2020, doi: 10.1002/jmv.25749.

[11] WHO, "Q\&A: Infection prevention and control for health care workers caring for patients with suspected or confirmed COVID-19," 2020. [Online]. Available: https://www.who.int/emergencies/diseases/nov el-coronavirus-2019/question-and-answershub/q-a-detail/q-a-on-infection-prevention-andcontrol-for-health-care-workers-caring-forpatients-with-suspected-or-confirmed-2019ncov. [Accessed: 15-Oct-2020].

[12] S. F. Rahmah, D. R. Mahda, T. Purwati, B. Suryo, and A. M. Nasution, "Edukasi Protokol Kesehatan dalam Menjalankan New Normal di Masa Pandemik Melalui Media Poster," Semin. Nas. Pengabdi. Masy. LPPM UMJ, vol. 1, no. 1, pp. 1-5, 2020.

[13] Ministry Of Women Empowerment And Child Protection, "Booklet Pelopor dan Pelapor Melawan COVID19,” 2020. [Online]. Available: https://www.kemenpppa.go.id/index.php/page/r ead/41/2616/anak-booklet-pelopor-danpelapor-melawan-covid19. [Accessed: 12-Jun- 
2020].

[14] D. K. Wardhani, L. J. Angghita, A. Ismail, and M. R. Susilorini, "Edukasi Pencegahan Penularan COVID-19 Pada Anak Usia Dini Melalui Media Pembelajaran Audio Visual," vol. 1, no. 3, pp. 131-136, 2020.

[15] R. Sholichah and N. R. Fadhilah, "Sosialisasi protokol kesehatan di masa pandemi melalui aktifitas mewarnai damar kurung pada anak usia dini," vol. 8, pp. 1-8, 2021.

[16] A. Prasetiyo and Sutama, "Media Internet Sebagai Sarana Edukasi pada Anak Usia Dini," vol. 3, no. 2, pp. 43-46, 2020.

[17] H. F. Hanafi, M. H. Wahab, K. T. Wong, A. Z. Selamat, M. H. M. Adnan, and F. H. Naning, "Mobile Augmented Reality Hand Wash (MARHw): Mobile Application to guide community to ameliorate handwashing effectiveness to oppose Covid-19 disease," Int. J. Integr. Eng., vol. 12, no. 5, pp. 217-223, 2020, doi: 10.30880/ijie.2020.12.05.027.

[18] M. M. Mcclelland, F. J. Morrison, and D. L. Holmes, "Children at Risk for Early Academic Problems: The Role of Learning-Related Social Skills," vol. 329, no. 3, pp. 307-329, 2020.

[19] D. Ratnawati and Vivianti, "Game Edukasi Mobile 'Aku Suka Sayur' Berbasis Augmented Reality Untuk Anak Usia Dini,” vol. 1, no. 2, 2020.

[20] P. B. Herlandy, J. Al Amien, P. Pahmi, and A. Satria, "A Virtual Laboratory Application for Vocational Productive Learning Using Augmented Reality," J. Pendidik. Teknol. dan Kejuru., vol. 25, no. 2, pp. 194-203, 2019, doi: 10.21831/jptk.v25i2.26504.

[21] R. M. Yilmaz, S. Kucuk, and Y. Goktas, "Are augmented reality picture books magic or real for preschool children aged five to six ?," vol. 00, no. 00, 2016, doi: 10.1111/bjet.12452.

[22] R. T. Azuma, "A survey of augmented reality," Hughes Res. Lab., 1997, doi: 10.1561/1100000049.

[23] E. Hornecker and N. Zealand, "An Observational Study of Children Interacting with an," pp. 305-315, 2007.

[24] A. Clark and A. Dünser, "An interactive augmented reality coloring book," IEEE Symp. $3 D$ User Interfaces 2012, 3DUI 2012 - Proc., pp. 2012, 20, doi: 10.1109/3DUI.2012.6184168.

[25] Disney, "Color and play," 2019. [Online]. Available: https://www.onlycoloringpages.net/. [Accessed: 02-May-2020].

[26] J. McKenzie and D. Darnell, "The eye magic book," Cent. Child. Lit., pp. 1-57, 2003.

[27] M. Miftah, "Fungsi dan peran media pembelajaran sebagai upaya peningkatan kemampuan belajar siswa," J. Kwangsan, vol. 1, pp. 95-105, 2013.

[28] S. Utami and P. Utami, "Peningkatan Partisipasi Belajar dan Hasil Belajar Peserta Didik Teknik Audio Video di Masa Pandemi Covid-19 dengan WhatsApp Group," ELINVO (Electronics, Informatics, Vocat. Educ., vol. 5, no. 1, pp. 75-88, 2020.

[29] M. Mantasia and H. Jaya, "Pengembangan Teknologi Augmented Reality Sebagai Penguatan Dan Penunjang Metode Pembelajaran Di Smk Untuk Implementasi Kurikulum 2013," J. Pendidik. Vokasi, vol. 6, no. 3, p. 281, 2016, doi: 10.21831/jpv.v5i3.10522.

[30] J. Bacca, S. Baldiris, R. Fabregat, S. Graf, and Kinshuk, "Augmented reality trends in education: A systematic review of research and applications," Educ. Technol. Soc., vol. 17, no. 4, pp. 133-149, 2014.

[31] M. Khalid, B. Mokhtar, F. Mohamed, and M. S. Sunar, "Development of Mobile-based Augmented Reality Colouring for Preschool Learning," no. February 2019, 2018, doi: 10.1109/IC3e.2018.8632639.

[32] A. Ismayani, Membuat Sendiri Aplikasi Augmented Reality. Jakarta: Elex Media Komputindo, 2020.

[33] Borg and Gall, Educational Research: An Introduction, Fifth Edition, 5th ed. New York: Longman, 1983.

[34] Sugiyono, Metode Penelitian Kuantitatif Kualitatif Dan R\&D. Bandung: Alfabeta, 2016.

[35] A. Dhimas, Cara Mudah Merancang Storyboard untuk Animasi Keren, 1st ed. Yogyakarta: TAKA Publisher, 2013.

[36] Sriadhi, "Instrumen Penilaian Multimedia Pembelajaran," Instrumen Penilai. Multimed. Pembelajaran, no. July, 2019. 